\title{
Explaining the Onset of Cohabitation under Semi-presidentialism
}

\author{
Robert Elgie and Iain McMenamin \\ Dublin City University
}

\begin{abstract}
Semi-presidentialism - where the constitution provides for both a directly elected fixed-term president and a prime minister and cabinet collectively responsible to the legislature - is an increasingly common form of government. For many observers cohabitation is the Achilles heel of semi-presidentialism. This article aims to identify the conditions that are associated with the onset of cohabitation. We specify a number of hypotheses that predict the conditions under which cohabitation should occur. We then test our hypotheses on the basis of a new data set that records every case of cohabitation in all semi-presidential electoral democracies from 1989 to 2008 inclusive. We confirm that cohabitation is more likely to occur in countries with a premier-presidential form of semi-presidentialism and show that it is more likely to follow an election that occurs midway through a parliamentary or presidential term, and that when cohabitation follows a presidential election, it is likely to do so in a country where there is only a very weak president. Overall, we find that the conditions under which cohabitation is most likely to occur are also the ones where it is most easily managed. Thus, our findings imply that cohabitation is not likely to be as problematic as the existing literature would suggest.
\end{abstract}

Keywords: semi-presidentialism; cohabitation; premier-presidentialism; presidentparliamentarism; elections

Semi-presidentialism - where the constitution provides for both a directly elected fixed-term president and a prime minister and cabinet collectively responsible to the legislature - is an increasingly common form of government. Particularly since the fourth wave of democratisation in 1990, many countries, notably in Central and Eastern Europe, the former Soviet Union and sub-Saharan Africa, have adopted a semi-presidential constitution (Elgie, 2007b). One of the most recognisable features of semi-presidentialism is cohabitation - where there is a president from one party and a prime minister from an opposing party and where the president's party is not represented in the cabinet. This term was first used to describe the situation in France from 1986 to 1988 when the socialist president, François Mitterrand, shared power with a right-wing government led by Prime Minister Jacques Chirac. Since this time, many semi-presidential countries have experienced cohabitation. Indeed, for some countries, such as Mongolia, Poland and Portugal, cohabitation has now become a common feature of the political process.

For many observers cohabitation is the Achilles heel of semi-presidentialism. When the president and the prime minister, via the assembly, can both claim to be the legitimate source of political authority, then in young democracies the scene is set either for deadlock between the two camps, perhaps encouraging the military to intervene to break the 
stalemate, or for either the president or the prime minister to seize power unilaterally. Linda Kirschke (2007) has provided evidence to suggest that cohabitation has indeed been damaging to democracy in sub-Saharan African countries. Indeed, in Niger what might be called a 'textbook' case of cohabitation coincided with the collapse of democracy in 1995 (Villalón and Idrissa, 2005). In consolidated democracies, cohabitation does not pose a threat to the democratic system, but it can cause tensions within the executive. In France, the constitution was amended in 2000 to decrease the likelihood of cohabitation in the future. In short, whether or not cohabitation is ultimately destructive of democracy, it certainly poses problems of coordination within any executive. Therefore, understanding the conditions under which cohabitation is most likely to occur is an important political issue.

To date, there have been scarcely any systematic cross-national studies of cohabitation. Certainly, in individual cases there has been plenty of analysis, perhaps most notably in France where the topic has been studied in considerable detail, though predominantly by constitutional lawyers (e.g. Cohendet, 1993). There are also plenty of case studies that refer to the consequences of cohabitation as part of a more general narrative about the development of the political system. ${ }^{1}$ However, the only truly cross-national comparison to date can be found in Samuels and Shugart (2010). As part of a broader project on presidents, prime ministers and parties, they provide descriptive statistics showing that cohabitation is much more prevalent in countries with the premier-presidential subtype of semipresidentialism than in those with the president-parliamentary subtype (Samuels and Shugart, 2010, ch. 2). That said, while David Samuels and Matthew Shugart clearly identify the general institutional framework in which cohabitation is most likely to occur, they do not explore the more specific conditions under which it is found. As a result, there are plenty of questions that remain unanswered. Within a given regime type, is cohabitation merely the stochastic result of exogenous political factors such as the party system, or is it endogenous to particular institutional arrangements, such as the electoral timetable? What is the relationship between presidential power and the frequency of cohabitation? In this article, we are not concerned with the duration of cohabitation. Instead, we aim to identify the conditions that are most likely to be associated with the onset of cohabitation. First, we identify necessary, or virtually necessary, conditions for cohabitation. Then, we propose some probabilistic hypotheses about the conditions under which cohabitation is more likely. We test our hypotheses on the basis of a new data set that records every case of cohabitation in all semi-presidential electoral democracies from 1989 to 2008 inclusive. Our analysis is a combination of descriptive statistics and logistic regression. We find that cohabitation is strongly associated with particular types of electoral situation. We also find that the onset of cohabitation is often associated with the interaction of certain types of electoral situation and the degree of presidential power in a country.

Our findings have policy implications. We show that cohabitation can generally be avoided with the adoption of certain constitutional rules. We also find that the conditions under which cohabitation is most likely to occur are also the ones where it is most easily managed. Thus, even though we do not study the effects of cohabitation directly, our findings strongly imply that cohabitation is not likely to be as problematic as the existing literature would suggest. 


\section{Semi-presidentialism and Cohabitation}

The definition of semi-presidentialism has long been a source of debate. In this article, we use the definition that is now standard (Elgie, 1999; 2007a; Samuels and Shugart, 2010; Shugart, 2005; Skach, 2005). A country has a semi-presidential constitution when there is both a directly elected fixed-term president and a prime minister and cabinet collectively responsible to the legislature. The key point to note about this definition is that there is no requirement for the president to have 'quite considerable powers' (Duverger, 1980, p. 166). In other words, there is no behavioural element to it. The advantage of such a definition is that, when deciding which countries are semi-presidential, we do not have to make a subjective judgement call as to what constitutes 'quite considerable powers'. We simply need to read the constitution.

Whatever definition we use, semi-presidentialism is inextricably linked with the notion of cohabitation. Cohabitation is more than the situation where representatives from different parties hold the two main positions within the executive. For example, cohabitation is not where one coalition party holds the presidency and another coalition party holds the premiership. Instead, cohabitation is the situation where a president from one party holds power at the same time as a prime minister from an opposing party and where the president's party is not represented in the cabinet. Given that there are two sources of legitimacy under semi-presidentialism - the presidential election and the parliamentary election - there is always the potential that one political force may win one election and that an opposing force may win the other. Thus, the potential for cohabitation is always present under semi-presidentialism. For this reason, debates about the pros and cons of semi-presidentialism always involve at least some discussion of the effects of cohabitation.

The most common argument in favour of semi-presidentialism is that it can allow for a degree of power sharing between opposing forces (Moestrup, 2007). One party can occupy the presidency, another can occupy the premiership and, thereby, both can have a stake in the institutional system. In their work, Samuels and Shugart (2010) provide a variant of this argument. They state (p. 337): 'the most important potential advantage [of the premierpresidential subtype of semi-presidentialism] is the prospect of cohabitation, which does not necessarily offer parties the "best of both worlds" but at least offers the possibility to oscillate between the presidential and parliamentary worlds '. For Samuels and Shugart therefore the institutional flexibility of semi-presidentialism is an advantage. This flexibility expresses itself through the potential for a shift from a unified executive to cohabitation. To use their terms (Samuels and Shugart, 2010, p. 338), the 'parliamentarisation' of the system under cohabitation can act as a counterweight to the presidency.

The strength of Samuels and Shugart's argument lies in the fact that it results from a rigorous empirical study. However, they are almost a lone voice in their support of cohabitation. The standard wisdom is that cohabitation is problematic. For example, Alfred Stepan and Ezra Suleiman (1995, p. 399) see 'the possibility of constitutional conflict between two electorally legitimated executives [as] the central problem [of semipresidentialism]'. Sergio Fabbrini (1995, p. 133) states that '[h]erein lies the main weakness of semipresidentialism: the possibility of a rift between the president with his popular 
majority and the premier with his legislative majority. Such a split could hamper or even paralyze the executive'. Juan Linz and Alfred Stepan (1996, p. 286) are more explicit still:

When supporters of one or the other component of semi-presidentialism feel that the country would be better off if one branch of the democratically legitimated structure of rule would disappear or be closed, the democratic system is endangered and suffers an overall loss of legitimacy, since those questioning one or the other will tend to consider the political system undesirable as long as the side they favor does not prevail ... [I]n a semipresidential system, policy conflicts often express themselves as a conflict between two branches of democracy.

For these writers cohabitation can be harmful for the very survival of democracy. However, in consolidated democracies too cohabitation is often a source of dissatisfaction. This is seen most clearly in France. The first experience of cohabitation from 1986 to 1988 'did not produce a fundamental political or constitutional crisis', but it did produce 'severe strains between the president and the prime minister' (Pierce, 1991, p. 287). President Mitterrand refused to sign certain government decrees; he returned a number of government bills to parliament for further consideration; and the prime minister encroached upon the president's 'reserved domain' of foreign and defence policy. The third period of cohabitation from 1997 to 2002, which began just two years into President Chirac's seven-year term, was even more 'devastating' (Quermonne, 2007, p. 6) in that it 'progressively slowed down the government's work and placed France's external relations in a difficult position, as witnessed in European affairs by the unfortunate Treaty of Nice'. ${ }^{2}$ The political response was the introduction of the five-year presidential term in 2000 and the de facto synchronisation of presidential and legislative elections. For those in favour of this constitutional reform, the desire to avoid cohabitation was the 'main benefit' (Bigaut, 2000, p. 11) that would accrue from it.

To summarise, cohabitation has been the source of considerable academic and political debate. To date, this work has overwhelmingly focused on the effects of cohabitation. It has shown that cohabitation can have important positive or, more usually, negative consequences. In short, it has been shown that cohabitation matters. In this article, we have a different aim. We wish to identify the conditions under which cohabitation is most likely to occur. Specifically, with what types of condition is cohabitation most likely to be associated? If we can identify regularities in the onset of cohabitation, then we can place the debate about the effects of cohabitation - good or bad - in its appropriate institutional context.

\section{Cohabitation in Semi-presidential Electoral Democracies}

We define cohabitation as the situation where a president from one party holds power at the same time as a prime minister from an opposing party and where the president's party is not represented in the cabinet. Whatever the party composition of the cabinet, if either the president or the prime minister is non-partisan or independent, then we do not class this as a case of cohabitation. To determine the party identification of the president and prime minister, we rely on the affiliations recorded in www.worldstatesmen.org. This is a reliable source and it standardises such affiliations as far as possible. To determine the party 
composition of cabinets, we use secondary sources, including publications such as Africa Research Bulletin and the European Journal of Political Research Political Data Yearbook.

We identify every occurrence of cohabitation in all countries with a semi-presidential constitution that are recorded as electoral democracies by Freedom House to 2008 inclusive. Their time series for electoral democracies goes back to 1989 inclusive. ${ }^{3}$ While we could have increased our units of observation by using data sets with longer time series, for example, Freedom House's Freedom in the World democracy scores or Polity IV scores, we rely on the electoral democracy classification partly because the time series is long enough to capture the increase in the number of semi-presidential countries after 1990 and also because we do not have to impose a cut-off point as to what score constitutes the threshold above which a country can be classed as a democracy. For the purposes of this study, therefore, if a country with a semi-presidential constitution is classed as an electoral democracy, then we include it in our data set. If such a country is first classified as an electoral democracy some time after 1989, we record it only from the year when it achieved this status. If a country loses the status of an electoral democracy, then we cease to include it in our data set. However, if the same country is reclassified as an electoral democracy at a later date, then we record it in our data set from that year on.

In our data set, the basic unit of observation is an electoral period. This comprises the time between a presidential or parliamentary election. Each unit of observation is a potential period of cohabitation. We are not concerned with the duration of cohabitation, only with whether or not cohabitation occurs in the first place. Therefore, we treat each electoral period, whatever its length, as one unit of observation. For example, Lithuania is first classed as an electoral democracy in 1991. However, it adopted a semi-presidential constitution in September 1992. The observations begin with the first direct presidential election in February 1993. There was then a parliamentary election in October/November 1996, a presidential election in December 1997/January 1998, a parliamentary election in October 2000, a presidential election in December 2002/January 2003, another presidential election in June 2004 following the impeachment of President Rolandas Paksas, a parliamentary election in October 2004, and a further parliamentary election in October 2008. This gives us eight units of observation for Lithuania (1993-1996, 1996-1998, 1998-2000, 2000-2003, 2003-2004, 2004, 2004-2008, and 2008-). There are two periods of cohabitation. The first was from 1996-1998 when President Algirdas Brazauskas from the Democratic Labour Party of Lithuania was faced with Prime Minister Gediminas Vagnorius from the Homeland Union-Conservatives of Lithuania who headed a three-party coalition in which the president's party was not represented. The second was from 2003-2004 when President Rolandas Paksas from the Liberal Democratic Party was opposite Prime Minister Algirdas Brazauskas who then represented the Social Democratic Party of Lithuania and who also headed a coalition in which the president's party was not represented. In the other seven units of observation for Lithuania either the president was classed as non-partisan or the president's party was represented in the government. In all, we have 218 units of observation, including 43 units, or periods, of cohabitation. ${ }^{4}$ Table 1 lists the countries that are included in the study, the periods when they have been classed as electoral democracies and whether they have a president-parliamentary or premier-presidential subtype of semi- 
Table 1: Semi-presidential Electoral Democracies, 1989-2008 Inclusive

\begin{tabular}{|c|c|c|}
\hline Country & Years included in data set & Subtype of semi-presidentialism \\
\hline Armenia & 1999-2002 & President-parliamentary \\
\hline Austria & $1989-$ & President-parliamentary \\
\hline Bulgaria & 1992- & Premier-presidential \\
\hline Cape Verde & $1991-$ & Premier-presidential \\
\hline Central African Rep. & 1991-2000, 2005-7 & President-parliamentary \\
\hline Congo-Brazzaville & $1992-6$ & Premier-presidential \\
\hline \multirow[t]{2}{*}{ Croatia } & $1991-$ & President-parliamentary (to 2000) \\
\hline & & Premier-presidential (from 2001) \\
\hline Finland & 1989 & Premier-presidential \\
\hline France & $1989-$ & Premier-presidential \\
\hline Guinea-Bissau & $1994-2002,2005-$ & President-parliamentary \\
\hline Haiti & $1995-9,2006-$ & Premier-presidential \\
\hline Iceland & 1989 & President-parliamentary \\
\hline Ireland & 1989 & Premier-presidential \\
\hline Lithuania & 1993- & Premier-presidential \\
\hline Macedonia & $1992-$ & Premier-presidential \\
\hline \multirow[t]{2}{*}{ Madagascar } & $1993-$ & Premier-presidential (to 1995) \\
\hline & & President-parliamentary (from 1996) \\
\hline Mali & $1992-$ & Premier-presidential \\
\hline Mauritania & $2007-8$ & President-parliamentary \\
\hline Moldova & $1995-2000$ & Premier-presidential \\
\hline Mongolia & $1992-$ & Premier-presidential \\
\hline Montenegro & $2006-$ & Premier-presidential \\
\hline Mozambique & $1994-$ & President-parliamentary \\
\hline Namibia & $1990-$ & President-parliamentary \\
\hline Niger & 1993-6, 1999- & Premier-presidential \\
\hline Peru & 1989-91, 2001- & President-parliamentary \\
\hline Poland & $1991-$ & Premier-presidential \\
\hline Portugal & 1989 & Premier-presidential \\
\hline Romania & $1992-$ & Premier-presidential \\
\hline Russia & 1993-2003 & President-parliamentary \\
\hline \multirow[t]{2}{*}{ São Tomé e Príncipe } & $1991-$ & President-parliamentary (to 2002) \\
\hline & & Premier-presidential (from 2003) \\
\hline Senegal & $2000-$ & President-parliamentary \\
\hline Serbia & $2006-$ & Premier-presidential \\
\hline Slovakia & 1999 & Premier-presidential \\
\hline Slovenia & $1992-$ & Premier-presidential \\
\hline Sri Lanka & 1989 & President-parliamentary \\
\hline Taiwan & $1996-$ & President-parliamentary \\
\hline Timor-Leste & $2002-$ & Premier-presidential \\
\hline Turkey & 2007- & Premier-presidential \\
\hline \multirow[t]{2}{*}{ Ukraine } & $1994-$ & President-parliamentary (to 2006) \\
\hline & & Premier-presidential (from 2007) \\
\hline
\end{tabular}

Source for electoral democracies: Freedom House, http://www.freedomhouse.org/template.cfm?page=439 [accessed 9 February 2010]. 
Table 2: Periods of Cohabitation in Semi-presidential

Electoral Democracies, 1989-2008 Inclusive

\begin{tabular}{ll}
\hline Country & \multicolumn{1}{c}{ Period of cohabitation to end 2008 } \\
\hline Austria & $2004-7$ \\
Bulgaria & $1995-7,2001-2,2002-5$ \\
Finland & $1991-4,1994-5,2007-$ \\
France & $1993-5,1997-2002$ \\
Iceland & $1996-9,1999-2000,2000-3,2003-4,2004-7$ \\
Ireland & $1990-2,1997$ \\
Lithuania & $1996-8,2003-4$ \\
Macedonia & $2002-4,2006-8,2008-$ \\
Mongolia & $1993-6,1997-2000$ \\
Niger & $1995-6$ \\
Poland & $1991-3,1993-5,1997-2000,2000-1,2007-$ \\
Portugal & $1987-91,1991,1991-5,2002-5,2006-$ \\
Romania & $2007-8$ \\
São Tomé & $1994-6,1996-9,1999-2001,2004-5$ \\
Serbia & $2006-7$ \\
Slovakia & $2004-6$ \\
Slovenia & $2004-6$ \\
Sri Lanka & $2001-4$
\end{tabular}

presidentialism (see H5 below). Table 2 lists the periods of cohabitation in these countries. Table 3 lists periods of non-partisan presidencies in these countries. There are 44 units of observation with non-partisan presidents. We present relevant descriptive statistics hypothesis by hypothesis.

\section{Explaining the Onset of Cohabitation}

\section{Under what Conditions is Cohabitation Likely to Occur?}

The first condition is the absence of a majority for the president's party in the legislature. While we would hesitate to raise this or any condition to that of a true 'sociological law', we can certainly treat it as a de facto necessary condition for cohabitation. By definition, under semi-presidentialism the government is responsible to the legislature. If the president is partisan and if the president's party has a majority in the legislature, then it is difficult to imagine the circumstances under which the president's party would not be represented in the government. Any attempt to install a government without the president's party would result in it being voted out of office by the presidential majority. So cohabitation will, inevitably, be associated with situations where the president's party fails to enjoy the support of an absolute majority in the legislature.

H1. Cohabitation will occur when the president's party has less than 50 per cent of the seats in the legislature. 
Table 3: Units of Non-partisan Presidencies in Semi-presidential Electoral Democracies, 1989-2008 Inclusive

\begin{tabular}{ll} 
Country & \multicolumn{1}{c}{ Non-partisan presidents to end 2008} \\
\hline Armenia & $1999-2002$ (president-parliamentary) \\
Central African Rep. & 2005-7 (president-parliamentary) \\
Croatia & $2000-3,2003-5,2005-7,2007-$ (premier-presidential) \\
Iceland & $1988-91,1991-2,1992-5,1995-6$ (president-parliamentary) \\
Lithuania & $1998-2000,2000-3,2004,2004-8$ (premier-presidential) \\
Macedonia & $1992-4,1994-8,1998-9$ (premier-presidential) \\
Mali & $2002-7,2007-$ (premier-presidential) \\
Mauritania & 2007 (president-parliamentary) \\
Moldova & $1995-6,1996-8,1998-2000$ (premier-presidential) \\
Russia & $1993-5,1995-6,1996-9,1999-2000,2000-3$ (president-parliamentary) \\
São Tomé & $1991-4,1994-6$ (president-parliamentary) \\
Slovakia & $2006-$ (premier-presidential) \\
Slovenia & $1992-6,1996-7,1997-2000,2000-2,2006-7$ (premier-presidential) \\
Timor-Leste & $2002-7,2007-$ (premier-presidential) \\
Ukraine & $1994-8,1998-9,1999-2002,2002-4$ (president-parliamentary)
\end{tabular}

Unsurprisingly, the empirical evidence supports this hypothesis. We calculated the percentage of seats held by the president's party in each of the units of observation and we found that all of the periods of cohabitation occurred when the president's party failed to enjoy majority support in the legislature. For example, in Portugal the Socialist party won the parliamentary election in February 2005, returning 52.6 per cent of the total number of deputies to the legislature and forming a single-party government. At the time, the incumbent president was Jorge Sampaio, also representing the Socialist party. So there was no cohabitation. However, in January 2006 Aníbal Cavaco Silva, representing the centreright Social Democratic party, won the presidential election. The Social Democrats enjoyed the support of 32.6 per cent of deputies in the legislature that had been elected the previous year. With the Socialists still enjoying an absolute majority there, the government did not change and a period of cohabitation began. This example clearly shows that the onset of cohabitation was associated with the shift from a situation where the president's party enjoyed majority support in the legislature to one where the president's party was in a minority.

While cohabitation is almost inconceivable in situations where the president's party enjoys majority support in the legislature, such an outcome is relatively uncommon. In fact, in our data set the president's party enjoyed the support of an absolute majority in the legislature in only 40 of 218 observations (18.3 per cent) in total and in 40 of the 175 observations (22.9 per cent) that remain when we exclude the observations where the president was non-partisan, and where, by definition, the president's party could not enjoy majority support. Therefore, while the absence of an absolute majority for the president's party in 
the legislature is a necessary condition for cohabitation, we still need to identify the circumstances in which cohabitation occurs when the president's party does not enjoy majority support there.

In this context, we begin by noting that cohabitation can occur as a result of three types of electoral situation: when synchronised presidential and legislative elections return opposing majorities; when a presidential election returns a candidate who is in opposition to the incumbent legislative majority (as in the previously cited Portuguese example); and when a legislative election returns a majority that is opposed to the incumbent president (as happened in France in 1986, 1993 and 1997). The only other situation under which we would observe cohabitation is if it were to occur midway through an electoral period. We hypothesise that this latter scenario is highly unlikely. Cohabitation could occur if the president's party were to withdraw unilaterally from the government. However, all else being equal, the president's party is unlikely to do so because it would leave the president totally alone within the executive. Cohabitation could also occur if the incumbent government was voted down by the legislature and a new government was formed that excluded the president's party. However, if the legislature were to vote down a government that included the president's party, it is likely that the president would still be able to avoid cohabitation. By virtue of his or her popular legitimacy, the president may be in a position to insist on his or her party being included in the new government, or to require a non-party technical government. Alternatively, the president may decide to dissolve the legislature rather than accept an unexpected period of cohabitation and potential loss of influence. So while cohabitation can occur outside an electoral context, it is very unlikely to do so.

H2. Cohabitation only occurs after elections.

Our data set strongly supports this hypothesis. Only two of the 43 cases of cohabitation began midway through an electoral period: in Romania from April 2007 until the election of December 2008 and in São Tomé e Príncipe from March 2004 until the president's party rejoined the government in June 2005. ${ }^{5}$ The Romanian case illustrates the exceptional circumstances that need to combine to lead to cohabitation occurring outside an electoral context. Following the 2004 legislative election, President Băsescu's Democratic Liberal party (PD-L) was part of the governing coalition led by Prime Minister Popescu-Tăriceanu of the National Liberal party (PNL) that included the PNL, the PD-L and two other parties. However, relations between the president and prime minister deteriorated so much that in April 2007 Prime Minister Popescu-Tăriceanu proposed a cabinet reshuffle that excluded the PD-L ministers from the new government (Stan and Zaharia, 2008, p. 1120). A couple of weeks later, parliament voted to impeach President Băsescu, accusing him of authoritarianism. In May a referendum was held to validate the impeachment vote. Turnout was relatively low, but the vote was overturned. Both the president and the government remained in office and cohabitation continued until the legislative election in December 2008 , but the fact that the onset of cohabitation midway through an electoral period coincided with parliament voting to impeach a president and a referendum on the president's survival in office shows that this scenario is likely to be associated with only an 
exceptional political situation. Overall, our findings provide overwhelming support for the proposition that cohabitation is likely to follow an election. ${ }^{6}$

Given that cohabitation is highly unlikely to occur outside an electoral context, the question arises as to whether particular types of election are more or less likely to lead to cohabitation. In this regard, we can hypothesise that cohabitation is unlikely to occur when presidential and parliamentary elections are synchronised. For cohabitation to occur under such conditions, there would have to be considerable split-ticket voting. While presidential elections are necessarily majoritarian, the legislative election would have to return a coherent majority that was actively opposed to the president. This is possible, but unlikely. As noted previously, in France the length of the president's mandate was changed deliberately to minimise the future likelihood of cohabitation. By contrast, in 2003 the president's term in Romania was increased from four to five years. Previously, presidential and parliamentary elections had been held simultaneously with the former acting as a 'trailblazer' in terms of government selection (Tănăsescu, 2008, p. 69). By 'desynchronising' the elections, the 2003 reform was not designed specifically to encourage cohabitation, but it was passed with a view to reducing the pre-eminence of the president in the political process, which is consistent with the general effect of cohabitation.

H3. Cohabitation will not occur when presidential and legislative elections are synchronised.

Again, descriptive statistics are sufficient to provide strong support for this hypothesis. In 50 of our 218 observations (22.9 per cent) presidential and legislative elections were held within three months of each other. For example, in Mozambique, Namibia and Romania (until 2008) the constitution specified simultaneous elections. In other countries, simultaneous (or quasi-simultaneous) elections were simply a function of the electoral timetable, as with the above case of Slovenia in 1992. However, none of these 50 observations resulted in cohabitation. In other words, the evidence strongly suggests that cohabitation is overwhelmingly likely to occur after a 'mid-term' election, that is to say following a legislative election that occurs at some point during a president's term or following a presidential election that occurs at some point during a legislature's term.

We have already shown that cohabitation is unlikely ever to be associated with the situation where the president's party enjoys an absolute majority in the legislature. By the same logic, even when the president's party does not enjoy majority support, we would expect cohabitation to be less likely when the president's party has more support in the legislature than when the president's party is only a small force. True, if there was a two-party system, then the president's party could win a very large minority of seats in the legislature and cohabitation could still occur because the opposition would have a majority. However, all else being equal, if the president's party has a very large minority of seats, then it is highly likely that the president's party will be an indispensable part of the coalition-building process, thus ensuring that cohabitation is avoided. By contrast, if the president heads a party with little support in the legislature, then, even though the president may have considerable personal legitimacy by virtue of being directly elected, the parliamentary arithmetic may mean that the president's party is not required for the construction of a stable legislative majority. 
H4. When the president's party does not have majority support in the legislature, cohabitation is less likely to occur as the share of the seats held by the president's party increases.

To test this hypothesis, we perform a logistic regression of cohabitation as predicted by the share of the seats held by the president's party in the legislature when the seat share is 50 per cent or less. The sample also excludes non-partisan presidents. The mean presidential share was almost 31 per cent, with a standard deviation of 13 , a minimum of zero and a maximum, by construction, of 50. Unsurprisingly, as Table 4 shows, we find that this variable is quite powerful, explaining over 11 per cent of the variation in this sample. The presidential share has an obvious substantive importance. For example, the model predicts that if the seat share of the president's party in the legislature were to fall from 30 to 20 per cent the probability of cohabitation would rise from 0.29 to 0.44 , an increase of over 50 per cent. In all subsequent models, we restrict the sample to cases where the president's party did not enjoy more than 50 per cent of the seats in the legislature.

In their recent book, Samuels and Shugart (2010) have shown that cohabitation is more likely to be associated with the premier-presidential subtype of semi-presidentialism than with the president-parliamentary subtype. The difference between the two subtypes is constitutional: under president-parliamentarism the president has the power unilaterally to dismiss the prime minister, whereas under premier-presidentialism this power is absent. Samuels and Shugart (2010, ch. 2) argue that parties are more likely to be presidentialised under the president-parliamentary subtype due to the importance that is placed on winning the presidency. Given that presidents have greater influence over legislative parties under this subtype (Samuels and Shugart, 2010, p. 55), there are likely to be greater opportunities, they argue, for presidents to avoid cohabitation than under premier-presidentialism. Samuels and Shugart provide a ready-made hypothesis for us to test. Moreover, they also provide us with an excellent opportunity to test the external validity of our findings. This is because they use the same definition of semi-presidentialism and cohabitation as this study, but they also use quite different case selection criteria when compiling their

Table 4: Logit Model of Presidential Share and Cohabitation

\begin{tabular}{lcc} 
& \multicolumn{2}{c}{ Model 1 } \\
\cline { 2 - 3 } & Coefficient & Standard error \\
\hline Presidential share & -0.0646 & $0.0194^{* * *}$ \\
Constant & 1.09 & 0.685 \\
Wald chi $^{2}$ & \multicolumn{2}{c}{$11.13^{* * *}$} \\
Pseudo $\mathrm{R}^{2}$ & \multicolumn{2}{c}{0.11} \\
Observations & 133 \\
States & 27
\end{tabular}

Notes: * Significant at $p<0.1 ;{ }^{* *}$ significant at $p<0.05 ;{ }^{* * *}$ significant at $p<0.01$. Robust standard errors clustered by state. 
cross-national data set and they calculate the incidence of cohabitation differently. They include countries only when they have scored at least +5 on the Polity IV scale for at least five consecutive years in the period from 1945 to 2007 inclusive (Samuels and Shugart, 2010 , p. 40). Also, they identify the incidence of cohabitation on the basis of the total percentage of years that semi-presidential democracies have experienced this situation. ${ }^{7}$ If we can replicate their finding about the greater likelihood of cohabitation in countries with a premier-presidential subtype of semi-presidentialism, then we can identify a further condition under which the onset of cohabitation is likely to occur and we can also have confidence in our findings more generally.

H5: Cohabitation is more likely in countries with a premier-presidential form of semipresidentialism than in those with a president-parliamentary form.

To test this hypothesis we conduct a logit of cohabitation as predicted by the subtype of semi-presidentialism controlling for the share of the president's party's seats in the legislature. The result (Table 5, Model 1) fails to reproduce Samuels and Shugart's finding that cohabitation is associated with premier-presidentialism. However, the result is driven by the very influential outlying case of São Tomé e Príncipe, which has a presidentparliamentary form of semi-presidentialism. This small African country of 160,000 inhabitants was excluded from Samuels and Shugart's study by Polity's size criterion. There were four periods of cohabitation in São Tomé e Príncipe between 1994 and 2005. However, in our sample there was only one other case of cohabitation in a president-parliamentary regime: Sri Lanka 2001-4. If we exclude São Tomé e Príncipe, 81 per cent of the observations are premier-presidential and the balance, of course, are president-parliamentary. As Table 5, Model 2 shows, the coefficient for premierpresidentialism more than doubles in size and reaches statistical significance. Holding presidential share at the mean for this sample (30 per cent), a premier-presidential regime has a 0.34 probability of cohabitation, while a president-parliamentary regime has a probability of less than 0.04 .

Table 5: Logit Models of Regime Type and Cohabitation

\begin{tabular}{|c|c|c|c|c|}
\hline & \multicolumn{2}{|c|}{ Model 1} & \multicolumn{2}{|c|}{ Model 2} \\
\hline & Coefficient & Standard error & Coefficient & Standard error \\
\hline Presidential share & -0.0603 & $0.018^{* * *}$ & -0.0654 & $0.019 * * *$ \\
\hline Premier-presidentialism & 1.14 & 0.905 & 2.586 & $1.252^{* *}$ \\
\hline Constant & 0.0221 & 1.084 & -1.287 & 1.185 \\
\hline Wald chi' & \multicolumn{2}{|c|}{$14.01^{* * *}$} & \multicolumn{2}{|c|}{$12.84^{* * *}$} \\
\hline Pseudo $\mathrm{R}^{2}$ & \multicolumn{2}{|c|}{0.14} & \multicolumn{2}{|c|}{0.18} \\
\hline Observations & \multicolumn{2}{|c|}{133} & \multicolumn{2}{|c|}{126} \\
\hline States & \multicolumn{2}{|c|}{27} & \multicolumn{2}{|c|}{26} \\
\hline
\end{tabular}

Notes: ${ }^{*}$ Significant at $p<0.1 ;{ }^{* *}$ significant at $p<0.05 ;{ }^{* * *}$ significant at $p<0.01$. Robust standard errors clustered by state. 
These results suggest that premier-presidentialism has a large and direct impact on the likelihood of cohabitation. However, it is also possible that premier-presidentialism may be associated with a lower seat share for the president's party. Given that we have just demonstrated that this is a necessary condition for cohabitation, premier-presidentialism's effect on cohabitation may be indirect, biasing our estimates of the direct effects of premier-presidentialism. To address this possibility, we conducted a number of Heckman probit models, which tested the effect of these two different causal channels from regime subtype to cohabitation. In no version was there evidence that a single-equation structure like that presented in Table 5 would bias estimates of the effect of premier-presidentialism. Thus, we can be confident that premier-presidentialism has a direct impact on the likelihood of cohabitation. From this point on we control for regime subtype but, when we do so, we exclude São Tomé e Príncipe.

As we have shown, cohabitation is highly unlikely to follow a mid-term election. The question therefore remains as to whether it is more likely to be associated with a presidential election that occurs at some point during a legislative term or with a legislative election that occurs at some point during a presidential term. All else being equal, we assume that cohabitation is more likely to follow a mid-term legislative election than a mid-term presidential election. If cohabitation follows a mid-term legislative election, then even if the president has the power to dissolve the legislature this power is unlikely to be available politically because an immediate dissolution would be likely merely to confirm the result of the previous legislative election. As a result, the president will have to accept a period of cohabitation before, in practice, the power to dissolve becomes operational. By contrast, if cohabitation follows a mid-term presidential election, then a president who has the power to dissolve the legislature will immediately do so in the hope of returning a pro-presidential majority or at least avoiding a pro-opposition majority. This was the strategy adopted by President Mitterrand in France following his election in 1981 and his re-election in 1988. Moreover, even if the president does not have the power to dissolve the legislature, mid-term presidential elections often provide the opportunity to reshape the party system, breaking old alliances and encouraging new coalitions. Therefore, a newly elected president may be able to forge a workable majority or at least avoid a hostile majority even without a legislative election.

H6. When cohabitation follows an election, it is more likely to follow a legislative election than a presidential election.

In order to test this hypothesis, we add a dummy variable for legislative, as opposed to presidential, elections -63 per cent of the observations were legislative elections and the rest were presidential. We also control for the subtype of semi-presidentialism and for the share of the president's party's seats in the legislature. The results do not support this hypothesis. Model 4 shows that the coefficient is in the wrong direction and does not approach significance (see Table 6). There are plausible reasons why the simple hypothesis does not work. In semi-presidential countries, presidential elections are often held under a two-ballot system. Under such a system, the eventual winner may be well short of a plurality at the first ballot, but may still win a plurality at the second ballot when faced with a controversial opponent. In such a case, the president's party may perform only weakly at the subsequent 
Table 6: Logit Model of Election Type and Cohabitation

\begin{tabular}{|c|c|c|}
\hline & \multicolumn{2}{|c|}{ Model 4} \\
\hline & Coefficient & Standard error \\
\hline Presidential share & -0.0648 & $0.019 * * *$ \\
\hline Premier-presidentialism & 2.65 & $1.315^{* *}$ \\
\hline Legislative election & -0.223 & 0.462 \\
\hline Constant & -1.227 & 1.18 \\
\hline Wald chi & \multicolumn{2}{|c|}{$12.5^{* * *}$} \\
\hline Pseudo $R^{2}$ & \multicolumn{2}{|c|}{0.185} \\
\hline Observations & \multicolumn{2}{|c|}{126} \\
\hline States & \multicolumn{2}{|c|}{26} \\
\hline
\end{tabular}

Notes: * Significant at $p<0.1 ;{ }^{* *}$ significant at $p<0.05 ;{ }^{* * *}$ significant at $p<0.01$. Robust standard errors clustered by state.

legislative election and cohabitation may ensue. In addition, in some democracies presidents may have considerable personal appeal, but they may have only a weak and ambivalent relationship with political parties. Again, this may mean that they are popular, whereas their party remains only a minor political force.

While these reasons may account for why the simple hypothesis fails, we focus on the interaction between the power of the president and the type of election to explain the likelihood or otherwise of cohabitation. One of the consequences of a purely constitutional definition of semi-presidentialism is that the list of semi-presidential countries includes countries with weak presidents as well as those with strong presidents. We hypothesise that when cohabitation follows a presidential election it is more likely to do so if the president is weak. So far, we have assumed that cohabitation matters. However, if the president is weak, then cohabitation may not figure as a political issue at all. Parties may organise to win the presidential election simply because they are office seeking, but policy-seeking political competition will focus predominantly on the outcome of the legislative election. In these cases, the presidential election is, in effect, a second-order election. Ireland is a good example. Here, the term 'cohabitation' is absent from the political vocabulary, even though there have been occasions when the president has been from a party that has not been represented in government. In Ireland the president is a figurehead position. Very occasionally the president may express a different opinion from the government, usually on social issues (Tavits, 2009). For the most part, though, the presidency is a ceremonial office. While presidential elections are sometimes uncontested, usually when a popular incumbent is willing to stand again, they are the object of political competition and, on occasions, the competition has been fierce, notably in 1990 (O'Sullivan, 1990). Whatever the intensity of the presidential competition, the election to the lower house of the legislature is the overwhelming focus of political activity. As a result, while cohabitation may result from a presidential election, the outcome will be largely, if not totally, irrelevant to the decisionmaking process. Thus, even if parties want to win the presidential election, there are few 
costs to losing it and, hence, few costs to cohabitation. The same is not true in a country where the president has real constitutional powers.

H7. When cohabitation follows a presidential election, it is more likely to do so when there is a weak president.

To test this hypothesis, we measure presidential power as a continuous variable using Alan Siaroff's (2003) measure, which runs from 0 to $8 .{ }^{8}$ In the sample for Table 7 , Model 5 , the mean Siaroff score, is almost 3 with a standard deviation of over 2 and a range of 0 to $6 .{ }^{9} \mathrm{We}$ first show that, while the relationship between presidential power by itself and cohabitation is in the right direction, the coefficient is very small and statistically insignificant (see Table 7, Model 5). We then restricted the sample to presidential elections. Since there was no variation in cohabitation among president-parliamentary countries, with the exception of the outlier São Tomé, we have dropped the regime variable. The resulting analysis strongly supports our hypothesis: the presidential power coefficient is almost ten times larger and is now statistically significant (see Table 7, Model 6). The restriction to presidential elections and premier-presidentialism removes over 60 per cent of the observations, but only seven of the 26 countries. The mean in this sample is 2.5, a little lower than for Model 5. Again, the model's implications are substantively noteworthy. Holding presidential share at the sample mean of 29 per cent, a regime with maximum presidential power has a 0.29 probability of cohabitation, rising to 0.91 if the constitution scores the minimum for presidential power. More subtle shifts are also predicted to have a profound effect on cohabitation. Reducing the presidential power from one to two reduces the probability of cohabitation by $0.06 .{ }^{10}$ Descriptive statistics also help us to illustrate these findings. Cohabitation follows a presidential election on fourteen occasions. However, we find that the country with the highest Siaroff score that experienced cohabitation following a presidential election was pre-reform Finland in 1994 with a score of $4 .{ }^{11}$ Generally, we find that when cohabitation followed a presidential election it did so overwhelmingly in countries with weaker-than-average

Table 7: Logit Models of Presidential Power and Cohabitation

\begin{tabular}{|c|c|c|c|c|}
\hline & \multicolumn{2}{|c|}{ Model 5} & \multicolumn{2}{|c|}{ Model 6} \\
\hline & Coefficient & Standard error & Coefficient & Standard error \\
\hline Presidential share & -0.0664 & $0.019 * * *$ & -0.08 & $0.0225^{* * *}$ \\
\hline Premier-presidentialism & 2.448 & $1.233^{* *}$ & - & - \\
\hline Presidential power & -0.044 & 0.132 & -0.41 & $0.174^{* *}$ \\
\hline Constant & -1.018 & 1.285 & 2.295 & $0.95^{* *}$ \\
\hline Wald chi ${ }^{2}$ & \multicolumn{2}{|c|}{$12.75^{* * *}$} & \multicolumn{2}{|c|}{$14.07^{* * *}$} \\
\hline Pseudo $\mathrm{R}^{2}$ & \multicolumn{2}{|c|}{0.18} & \multicolumn{2}{|c|}{0.227} \\
\hline Observations & \multicolumn{2}{|c|}{126} & \multicolumn{2}{|c|}{48} \\
\hline States & \multicolumn{2}{|c|}{26} & \multicolumn{2}{|c|}{19} \\
\hline
\end{tabular}

Notes: * Significant at $p<0.1 ;{ }^{* *}$ significant at $p<0.05 ;{ }^{* * *}$ significant at $p<0.01$. Robust standard errors clustered by state. 
presidencies: Austria (adjusted Siaroff score of 0), Iceland (0), Ireland (1), Slovakia (1), Bulgaria (2), Lithuania (3), Mongolia (3), Poland (2) and Portugal (2).

Thus, while we find no support for the simple hypothesis that cohabitation is more likely to follow a legislative election, we find strong support for the proposition that the onset of cohabitation is indeed at least partly determined by the type of election. When cohabitation follows a presidential election, it is much more likely to do so in a country with a weak presidency than in one with a strong presidency.

\section{The Effect of Cohabitation and the Conditions under which it Occurs}

There is an ongoing debate as to whether semi-presidentialism constitutes a good constitutional choice. Central to this debate is the impact of cohabitation. While there is some support for the idea that cohabitation can have positive benefits, most observers believe that cohabitation is problematic. In this article, we have not examined the effects of cohabitation directly. Even so, our findings add to the debate about the pros and cons of cohabitation and to the debate about semi-presidentialism generally.

We have confirmed the finding from Samuels and Shugart (2010) concerning the effect of regime type on the incidence of cohabitation. Countries with the president-parliamentary subtype of semi-presidentialism are much less likely to experience cohabitation than those with the premier-presidential subtype. This finding is not driven by the greater presence of non-partisan presidents in the president-parliamentary countries in our data set. While non-partisan presidents are common in such countries generally, often they are common in countries that are not classed as electoral democracies. Therefore, these countries do not enter our data set in the first place. Indeed, in our sample 25 of the 44 observations with non-partisan presidents were found in premier-presidential countries (see Table 3 ). This suggests that if the overwhelming aim of constitution makers is the desire to avoid cohabitation, then semi-presidential countries should adopt a president-parliamentary form of semi-presidentialism. That said, studies have shown that president-parliamentarism is also much more likely to be associated with democratic collapse and with a lower quality of government (Elgie, 2007b; Elgie and McMenamin, 2008; Samuels and Shugart, 2010; Shugart and Carey, 1992). In this article we have shown that synchronised presidential and legislative elections, or quasi-synchronised elections, where both elections are held within three months of each other, are a very effective way of avoiding cohabitation even under a premier-presidential form of semi-presidentialism. Thus, we have shown that opponents of president-parliamentarism and cohabitation can have the best of both worlds - premierpresidentialism plus synchronised elections makes it very unlikely that cohabitation will occur.

Most observers believe cohabitation to be problematic. While we have not examined the effects of cohabitation directly, our findings imply that cohabitation may be less problematic than the received wisdom may suggest. For most scholars cohabitation is associated with problems of executive coordination. We have not tested for the direct effect of cohabitation in this regard, but our results provide indirect evidence for the belief that cohabitation may 
not be as problematic as the folk wisdom might suggest. We have shown that cohabitation is very unlikely to occur outside the context of an election. Given that democracies rest on the legitimacy of the electoral process, the fact that cohabitations overwhelmingly follow elections suggests that cohabitation is likely to be seen as a legitimate element of that process, albeit perhaps an unwanted one. If cohabitation is seen as legitimate, then the main political actors - president, prime minister, legislature - are likely to work within the framework with which they have been presented rather than undermine it. This does not mean that there will be an unexpected outbreak of political harmony, but it does suggest that actors will respect the boundaries of the constitutional process. The French experience of cohabitation strongly supports this proposition. No-one among the political class was very happy with cohabitation. Everyone wanted sole authority. However, the election result meant that this was not possible. Therefore, while the president was willing to intervene in a way that made the decision-making process more complex than had previously been the case, there was no legislative gridlock. The president did not try to dismiss the prime minister against the wishes of the majority. The majority did not refuse to propose a prime minister or refuse to cooperate by insisting on the resignation of the president. So, even though we have not tested for the effect of cohabitation on executive coordination, our findings suggest that any problems of coordination will occur in a context in which the main political actors are likely to respect the basic rules of the admittedly unusual game with which they are faced.

Building on this point, we have also shown that potentially the most problematic scenario in which cohabitation can occur - following a presidential election - is unlikely to be a source of contestation. Under semi-presidentialism, as under presidentialism, a general worry is that a president will rely on his or her personal authority and rule by decree, so undermining the legislative majority (Skach, 2005). We might imagine that if a newly elected president is unable to dissolve an opposition legislature and immediately faces a period of cohabitation, then even in a consolidated democracy the incentive for the president to act unilaterally in order to pursue his or her legitimate mandate may be overwhelming. The result may not be the collapse of democracy, but it could be the polarisation of the political process, leading to inefficient decision making. While the personalisation of presidential power may well be a general problem under semipresidentialism, particularly under its president-parliamentary subtype, we have found that it is unlikely to be a problem that results from cohabitation. We have shown that when cohabitation follows a presidential election, it is likely to do so in countries where the president is a relatively weak political actor. Indeed, we have found that it is often likely to do so in countries where the president is so weak that the concept of cohabitation is completely absent from the political vocabulary.

Overall, our findings suggest that the critics of cohabitation may have exaggerated its problems. We have shown that cohabitation is likely to occur in the context where it is easiest to manage. This does not mean that there will not be problems of executive coordination during cohabitation. It merely means that such problems are likely to occur in the most benign context possible. Thus, the negative impact of cohabitation may not be as great as the received wisdom would have us believe. 


\section{Conclusion}

Semi-presidentialism is closely associated with cohabitation. For most observers, cohabitation is a problem. In new democracies its effects can be so devastating that the process of democratisation itself may collapse. In consolidated democracies, it can lead to problems of executive coordination and legislative gridlock. In this article, we have provided the first systematic exploration of the conditions under which cohabitation is likely to occur. Cohabitation only occurs when the president's party fails to enjoy majority support in the legislature. In this context, we have confirmed that it is more likely to occur in countries with a premier-presidential form of semi-presidentialism. We have also shown that it is more likely to follow an election, and that it is likely to follow an election that occurs midway through a parliamentary or presidential term. We have also shown that when cohabitation follows a presidential election, it is likely to do so in a country where there is only a very weak president. Together, these findings have important policy implications. If constitution makers wish to avoid cohabitation at all costs, then we have identified a very clear strategy that maximises the chances of doing so. However, we have also suggested that there is perhaps less need to be concerned about cohabitation than the received wisdom would suggest. We find that the conditions under which cohabitation is most likely to occur are also the ones under which it is likely to be most easily managed. By itself, this finding does not provide support for semi-presidentialism. However, it does suggest that one of the most oft-cited problems of semi-presidentialism is less serious than the folk wisdom would suggest.

(Accepted: 13 April 2010)

\section{About the Authors}

Robert Elgie is Paddy Moriarty Professor of Government and International Studies at Dublin City University. He is co-editor of the journal French Politics published by Palgrave and also co-editor of the Routledge/ECPR 'Studies in European Political Science' series. He has published extensively on comparative politics, semi-presidentialism and French politics. He is currently preparing a book for Oxford University Press on semi-presidentialism and democratic survival.

Robert Elgie, School of Law and Government, Dublin City University, Dublin 9, Ireland; email: robert.elgie@dcu.ie

Iain McMenamin is a Senior Lecturer in the School of Law and Government, Dublin City University. His research interests range widely across comparative politics, but particularly emphasise business-government relations and Poland. He has published in the European Journal of Political Research, Public Choice, the British Journal of Political Science and other journals. He is currently working on a quantitative and qualitative study of political finance in Australia, Canada and Germany.

Iain McMenamin, School of Law and Government, Dublin City University, Dublin 9, Ireland; email: iain.momenamin@dcu.ie

\section{Notes}

Robert Elgie would like to thank the Irish Research Council for the Humanities and Social Sciences for the award of a Senior Research Fellowship in 2009-10 that was a great help in the preparation of this article. The authors would also like to thank the anonymous reviewers for their comments, which were very constructive and most helpful. The usual disclaimer applies.

1 See, for example, some of the contributions in Elgie and Moestrup, 2007; 2008.

2 All translations are by the author. 
3 The data are available from: http://www.freedomhouse.org/template.cfm?page=439.

4 We excluded Kyrgyzstan because we were unable to calculate the effective number of parliamentary parties and because we did not have sufficient constitutional information about the country.

5 In addition, one period of cohabitation ends mid-way through an electoral period. In Slovenia, President Janez Drnovšek officially left the Liberal Democracy of Slovenia party in January 2006 and became non-partisan, thus ending a period of cohabitation that began with the parliamentary election in October 2004.

6 These two cases and the Slovenian case from 2006-2007 (see note 5) lead us to a slightly different coding of our unit of observation. For example, in the case of Romania from 2004 to 2008 there are two units, one covering the period from the election of 2004 to the beginning of the period of cohabitation in 2007 and then one from this point until the next election in 2008. The minor measurement anomaly does not affect our results. Indeed, for many of our empirical analyses, for other reasons, São Tomé e Príncipe has been eliminated from the models, leaving only the Romanian and Slovenian non-electoral periods.

7 Their study raises operational issues in the classification of a handful of countries. We include Iceland and São Tomé, neither of which are part of the Polity IV data set on which Samuels and Shugart base their study, but both of which experience numerous periods of cohabitation. Samuels and Shugart classify Austria behaviourally as a 'parliamentarized president-parliamentary regime' (Samuels and Shugart, 2010, p. 106). They argue that, while constitutionally Austria has a president-parliamentary form of semi-presidentialism, the president's power, by convention, is so weak that 'Austrian politics does not follow the formal configuration of power its constitution outlines' (Samuels and Shugart, 2010, p. 107). Their solution is to exclude Austria from their list of cohabitations. (The same point applies to Ireland, even though formally it has a premier-presidential form of semi-presidentialism). The same logic can certainly be applied to Iceland, where, for the same reason, 'it is customary ... to regard the form of government as a parliamentary one' (Kristinsson, 1999, p. 86). In this article, we are not concerned with comparing parliamentarism, presidentialism and semi-presidentialism. Therefore, rather than excluding Austria and Iceland, we reclassify both countries as premier-presidential (i.e. as semi-presidential countries where, albeit by convention, the president does not dismiss the government). This is consistent with the logic of Samuels and Shugart's study.

8 In the original, Siaroff scores 1 for the direct election of the president. We omit this measure and recalculate the scores. We also recalculate the score for Ireland, where, contrary to Siaroff's coding, the president does not have the right to veto legislation.

9 We calculate the Siaroff scores for those countries not included in his study.

10 Presidential power is usually operationalised as a continuous variable, but it can also be thought of as a categorical variable. Since the distribution of the variable is somewhat skewed towards weaker presidents, we divided the data set into observations at or below the median and above the median. Using this as a dummy variable in Model 5 produces similar results to the continuous version, except that the premier-presidential indicator loses statistical significance. Inserting the presidential power dummy into Model 6 reproduces essentially the same results.

11 São Tomé, with a Siaroff score of 7, experienced cohabitation after its 1996 presidential election.

\section{References}

Bigaut, C. (2000) 'Du septennat au quinquennat: histoire et arguments', Regards sur l'actualité, Nov-Dec, 17.

Cohendet, M.-A. (1993) La cohabitation: leçons d'une expérience. Paris: PUF.

Duverger, M. (1980) 'A New Political System Model: Semi-presidential Government', European Journal of Political Research, 8 (2), 165-87.

Elgie, R. (1999) 'The Politics of Semi-presidentialism', in R. Elgie (ed.), Semi-presidentialism in Europe. Oxford: Oxford University Press, pp. 1-21.

Elgie, R. (2007a) 'What is Semi-presidentialism and Where is it Found?', in R. Elgie and S. Moestrup (eds), Semi-presidentialism Outside Europe. London: Routledge, pp. 1-13.

Elgie, R. (2007b) 'Varieties of Semi-presidentialism and Their Impact on Nascent Democracies', Taiwan Journal of Democracy, 3 (2), 53-71.

Elgie, R. and McMenamin, I. (2008) 'Semi-presidentialism and Democratic Performance', Japanese Journal of Political Science, 9 (3), 323-40.

Elgie, R. and Moestrup, S. (eds) (2007) Semi-presidentialism Outside Europe. London: Routledge.

Elgie, R. and Moestrup, S. (eds) (2008) Semi-presidentialism in Central and Eastern Europe. Manchester: Manchester University Press.

Fabbrini, S. (1995) 'Presidents, Parliaments, and Good Government', Journal of Democracy, 6 (3), 128-38.

Kirschke, L. (2007) 'Semipresidentialism and the Perils of Power-Sharing in Neopatrimonial States', Comparative Political Studies, 40 (11), 1372-94.

Kristinsson, G. H. (1999) 'Iceland', in R. Elgie (ed.), Semi-presidentialism in Europe. Oxford: Oxford University Press, pp. 86-103. 
Linz, J. J. and Stepan, A. (1996) Problems of Democratic Transition and Consolidation: Southern Europe, South America, and Post-communist Europe. Baltimore MD: The John Hopkins University Press.

Moestrup, S. (2007) 'Semi-presidentialism in Young Democracies: Help or Hindrance?', in R. Elgie and S. Moestrup (eds), Semi-presidentialism Outside Europe. London: Routledge, pp. 30-55.

O’Sullivan, E. (1990) 'The 1990 Presidential Election in the Republic of Ireland', Irish Political Studies, 6, 85-98.

Pierce, R. (1991) ‘The Executive Divided against Itself: Cohabitation in France 1986-88', Governance, 4 (3), $270-94$.

Quermonne, J.-L. (2007) 'Le président de la république: quelle place et quel rôle dans l'organisation des pouvoirs publics?', Cahiers français, 332. Paris: La Documentation française, pp. 3-8.

Samuels, D. and Shugart, M. (2010) Presidents, Parties, Prime Ministers: A Framework for Analysis. Cambridge: Cambridge University Press. Available from: http://dss.ucsd.edu/ mshugart/samuels-shugart.html [Accessed 22 July 2009].

Shugart, M. S. (2005) 'Semi-presidential Systems: Dual Executive and Mixed Authority Patterns', French Politics, 3 (3), $323-51$.

Shugart, M. S. and Carey, J. M. (1992) Presidents and Assemblies: Constitutional Design and Electoral Dynamics. Cambridge: Cambridge University Press.

Siaroff, A. (2003) 'Comparative Presidencies: The Inadequacy of the Presidential, Semi-presidential and Parliamentary Distinction', European Journal of Political Research, 42 (3), 287-312.

Skach, C. (2005) Borrowing Constitutional Designs: Constitutional Law in Weimar Germany and the French Fifth Republic. Princeton NJ: Princeton University Press.

Stan, L. and Zaharia, R. (2008) 'Romania', European Journal of Political Research, 47 (7), 1115-26.

Stepan, A. and Suleiman, E. N. (1995) 'The French Fifth Republic: A Model for Import?’ Reflections on Poland and Brazil', in H. E. Cheibub and A. Stepan (eds), Politics, Society, and Democracies: A Comparative Study. Boulder CO: Westview Press, pp. 393-414.

Tănăsescu, E. S. (2008) ‘The President of Romania, or: The Slippery Slope of a Political System’, European Constitutional Law Review, 4 (1), 64-97.

Tavits, M. (2009) Presidents with Prime Ministers: Do Direct Elections Matter? Oxford: Oxford University Press.

Villalón, L. A. and Idrissa, A. (2005) 'Repetitive Breakdowns and a Decade of Experimentation: Institutional Choices and Unstable Democracy in Niger', in L. A. Villalón and P. VonDoepp (eds), The Fate of Africa's Democratic Experiments: Elites and Institutions. Bloomington IN: Indiana University Press, pp. 27-48. 